\title{
Energy Resources Program of the U.S. Geological Survey
}

\section{Introduction}

Our Nation faces the simultaneous challenges of increasing demand for energy, declining domestic production from existing oil and gas fields, and increasing expectations for environmental protection. The Energy Information Administration (2000) forecasts that worldwide energy consumption will increase 32 percent between 1999 and 2020 because of growth of the world economy. Forecasts indicate that in the same time period, U.S. natural gas consumption will increase 62 percent, petroleum consumption will increase 33 percent, and coal consumption will increase 22 percent.

The U.S. Geological Survey (USGS) provides the objective scientific information our society needs for sound decisions regarding land management, environmental quality, and economic, energy, and strategic policy. To support this mission, the USGS Energy Resources Program-

- Periodically assesses national and world energy resources (fossil fuels) and their geologic framework,

- Evaluates the environmental and economic effects of production and use of fossil fuels, and

- Delivers energy resource information to the land and resource management bureaus of the U.S. Department of the Interior, other Federal agencies, State geological surveys, the energy industry, and the environmental community.

\section{U.S. Oil and Gas Resources}

The 1995 USGS National Oil and Gas Assessment Team (Gautier and others, 1996) concluded that our Nation's future energy supply will come from known U.S. oil and gas fields, from newly discovered natural gas deposits, and from imported petroleum. The 1990 Clean Air Act Amendments and concern about greenhouse gas emissions to the atmosphere have introduced a sense of urgency to identify the Nation's remaining deposits of clean-burning natural gas.

The USGS has begun an update of the 1995 national assessment that focuses

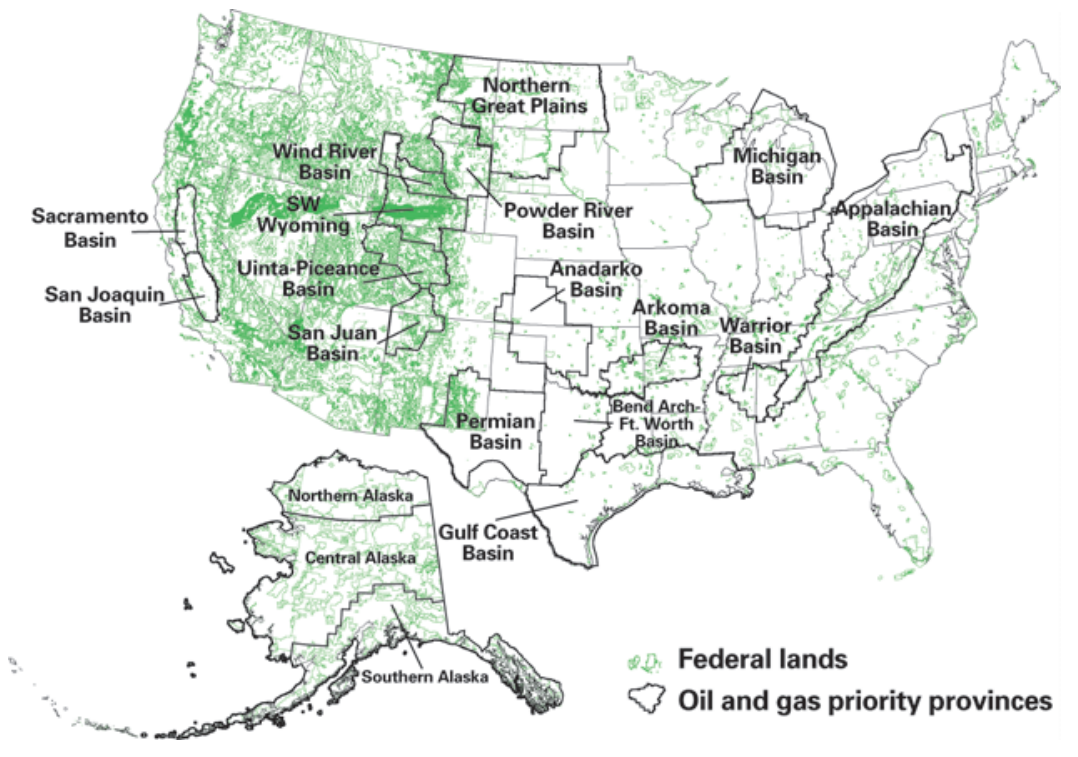

Figure 1. Onshore provinces that have high potential for production of natural gas, including coal-bed methane and gas hydrates. These priority provinces are being assessed as the USGS updates its 1995 National Oil and Gas Assessment.

on the Nation's natural gas endowment and the potential of additional reserves of oil and gas from existing fields in the United States. Research started in fiscal year (FY) 2000 and continuing through FY 2004 focuses on evaluating U.S. provinces (fig. 1) that have the best potential for production of natural gas and on improving the accuracy of natural gas resource assessments.

Alaska.-The North Slope of Alaska has the greatest remaining oil potential of any onshore area in the United States (fig. 2). The USGS is collaborating with the Alaska Division of Geological and Geophysical Surveys to conduct an intensive examination of the North Slope's petroleum potential; current research focuses on oil and gas resources of the National Petroleum Reserve-Alaska (NPRA) and the Yukon Flats area.

Large volumes of methane gas are stored below the permafrost of the North Slope in icelike structures known as gas hydrates. The USGS is assessing the recoverability, resource potential, environmental effects, and production characteristics of these gas hydrates; the USGS work is conducted in partnership with the U.S.
Department of Energy (DOE) and industry operators in Alaska. Although significant technological challenges will have to be overcome, in the long term, gas hydrates may be a major source of clean-burning methane for the Nation.

Gulf of Mexico Coast Region.-Like Alaska, the Gulf Coast region has a high potential for new oil and gas production. The USGS is conducting basic framework studies that are needed to identify and characterize the petroleum systems of the region in preparation for an assessment of undiscovered oil and gas resources. These studies focus on unconventional petroleum resources of the Austin Chalk, the deep gas in the Tuscaloosa Formation, and methane from the extensive coals and lignites of Texas, Louisiana, Mississippi, and Alabama.

\section{U.S. Coal Resources}

More than half of the electricity produced in the United States today is generated by coal-fired powerplants. The USGS National Coal Resource Assessment (NCRA) is a multiyear effort to (1) assess coal beds and zones that will be the most important for supply in the next few decades (fig. 3); 


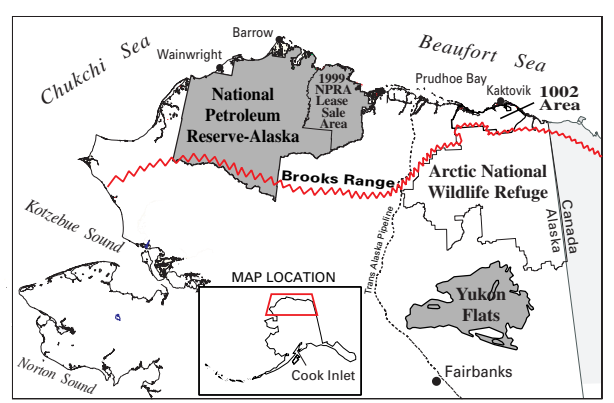

Figure 2. Project areas (dark gray) in northern and central Alaska for the current USGS National Oil and Gas Assessment. The North Slope is north of the Brooks Range.

(2) create publicly available digital databases of stratigraphic, geochemical, and geographic information to support government and industry decisionmakers and the public sector; and (3) provide interpretive geologic and geochemical information on the major coal resources of the Nation. The NCRA results are being released in USGS Professional Papers 1625-A through 1625-F.

\section{World Oil and Gas Resources}

In the United States, net imports now account for more than 50 percent of petroleum consumption and are predicted to increase to 64 percent in 20 years. Consequently, it is in the Nation's interest to know the distribution and quantity of the petroleum resources remaining in the world.

The USGS assessed the 76 most productive oil and gas provinces of the world, which contain about 95 percent of the remaining oil and gas resources (USGS World Energy Assessment Team, 2000). This assessment is the first of its kind to include a rigorous geologic foundation for remaining resource volumes, and it is the first to make those data available to the geoscience, business, and research communities. The U.S. Departments of Energy, Defense, and State; U.S. Agency for International Development; Energy Information Administration; International Energy Agency; the intelligence community; and over two dozen industry partners assisted in this effort.

\section{Environmental Issues}

The USGS Energy Resources Program studies the environmental effects of extracting and using fossil fuels. Coal environmental research focuses on the natural variability of coal quality and the environmental and human-health impacts of mining and using coal as an energy source. Areas of concern include sulfuric acid leached into surface and ground water from sulfur- bearing minerals exposed by coal mining, hazardous waters that are coproduced with oil and gas, coastal subsidence due to oil and gas withdrawals, and methane escaping from natural and manmade seeps.

The USGS provides the U.S. Environmental Protection Agency and DOE with reliable estimates of the amount and behavior of hazardous elements, such as mercury and arsenic, in the coal mined for power generation in this country. Additionally, the USGS is assessing the capacity of depleted oil and gas reservoirs, saline aquifers, and unminable coal beds to accept and sequester carbon dioxide produced by powerplants.

\section{Digital Information}

The USGS National Coal Quality Inventory (NaCQI), a digital database of the chemistry of coals used in powerplants, was established in FY 2000 and is expanding through collaboration with State geological surveys and the Electric Power Research Institute. These data will enable Federal and State regulatory agencies, electric power utilities, and the coal industry to quickly access and display detailed coal quality information to address air quality issues and to maintain compliance with the 1990 Clean Air Act Amendments. The USGS is also compiling a database of coal quality from around the world, the World Coal Quality Inventory (WoCQI). This database will provide information to help policymakers evaluate the environmental impacts of global coal use.

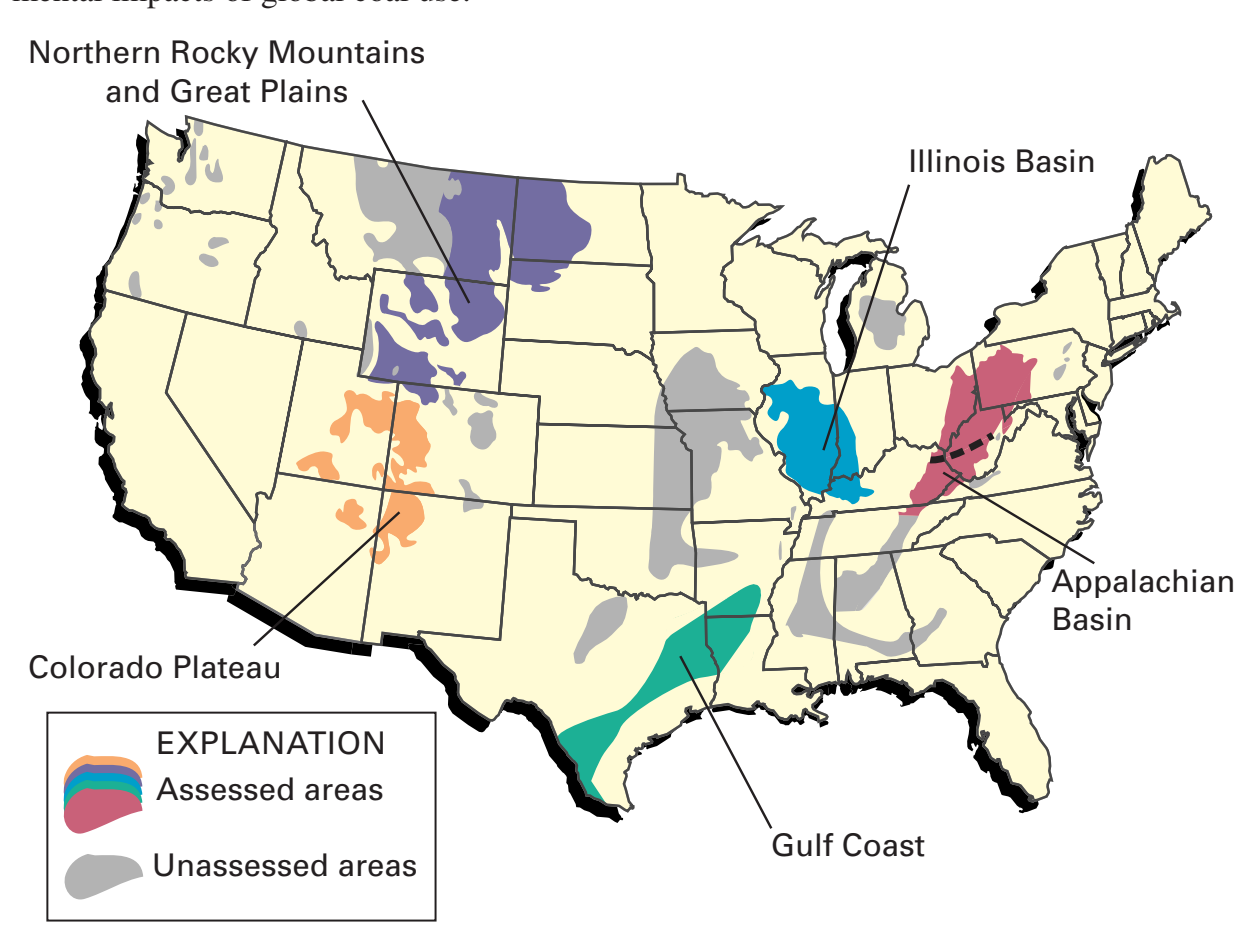

Figure 3. Five priority regions of the USGS National Coal Resource Assessment and unassessed coal-bearing areas of the conterminous United States.

\section{References Cited}

Energy Information Administration, 2000, Annual energy outlook 2001: Energy Information Administration Report DOE/EIA-0383(2001). (Available online at http://www.eia.doe.gov/ oiaf/aeo/.)

Gautier, D.L., Dolton, G.L., Takahashi, K.I., and Varnes, K.L., eds., 1996, 1995 National assessment of United States oil and gas resources-Results, methodology, and supporting data: U.S. Geological Survey Digital Data Series DDS-30, release 2, one CDROM.

U.S. Geological Survey World Energy Assessment Team, 2000, U.S. Geological Survey World Petroleum Assessment 2000-Description and results: U.S. Geological Survey Digital Data Series DDS-60, four CD-ROM's.

For more information, please visit the web sites at:

http://energy.usgs.gov

http://www.usgs.gov

Or contact:

Suzanne Weedman, Program Coordinator

Energy Resources Program

U.S. Geological Survey

915A National Center

Reston, VA 20192

Telephone: 703-648-6470

E-mail: sweedman@usgs.gov 